\title{
DETECTION OF CLINICALLY RELEVANT COPY NUMBER VARIATION OF SEZ6L2 GENE IN A BANGLADESHI AUTISM SPECTRUM DISORDER COHORT
}

\author{
K. M. FURKAN UDDIN ${ }^{1,2}$, MD. ROBED AMIN ${ }^{2,3}$, NASIMA SULTANA ${ }^{4}$, MD. ABDUL ALEEM ${ }^{5}$, SUPROVATH KUMAR \\ SARKER ${ }^{6}$, LAILA ANJUMAN BANU ${ }^{7}$, MOHAMMAD SHAHEB ALI ${ }^{8}$, WAHIDA KHANAM ${ }^{9}$, NARSIS RAHMAN ${ }^{9}$, MD. \\ ABDUL BAQUI ${ }^{1,2}$ HOSNEARA AKTER $^{2}$, NUSHRAT JAHAN DITY ${ }^{2}$ MD. AB ZIAUDDIN HOSSAIN ${ }^{10}$
}

\begin{abstract}
:
Introduction: Autism Spectrum Disorder (ASD) is a neurodevelopmental disorder. Due to long term impairment, high genetic component (heritability> 90\%), lack of effective prevention and treatment, ASD has been prioritized for genetic studies. Studies on Copy Number Variations (CNV) at chromosome $16 p 11.2$ locus have mostly been conducted in population of pure or predominant European ancestry. It is not known whether this is also prevalent among the ASD affected individuals in population of other ancestries such as Bangladeshi population. The aim of this research work is to detect CNV of SEZ6L2 gene at 16p11.2 locus and to describe the associated clinical characteristics in Bangladeshi cohort with clinically diagnosed ASD.

Methods: The known SEZ6L2 gene was interrogated for copy number variation (CNV) in twenty five autistic patients with SYBR Green I assay using the real time qPCR. Probands were interrogated using relative standard curve (efficiency correction) method. Epilepsy with speech disorder and postnatal infection might be more common among autistic patients with CNV at this SEZ6L2 gene.

Results: The two cases with characteristics CNV was detected who had clinically manifestation of convulsion at different ages, partial developmental delay in multiple domains including delay in walking, speech delay and mental age not corresponding with the chronological age. This work describes the frequency of CNV is $8.3 \%$. This rate is skewed due to small sample size and do not reflect the true frequency of $16 p 11.2$ duplication impacting SEZ6L2 gene.
\end{abstract}

Conclusion: Epilepsy with speech disorder and postnatal infection might be more common among autistic patients with CNV at this SEZ6L2 gene.

Received: 13 September 2018

Accepted: 05 November 2018

DOI: https:// doi.org/10.3329/bjmed.v30i1.39919

\section{Introduction:}

Autism Spectrum Disorder (ASD, MIM 209850) is a neurodevelopmental disorder characterized by impairments in three major domain s reciprocal-social interaction; communication deficit; and repetitive \& restricted patterns of behavior and interest. ASD include four disorder (i) Autism, (ii) Asperger's
Syndrome, (iii) Childhood Disintegrative Disorder and (iv) Pervasive Developmental Disorder-Not Otherwise Specified (PDD-NOS) which differ with regard to symptom severity and early development of language, cognitive and social behavior. ${ }^{1}$ Autism spectrum disorder is clinically highly heterogeneous and overlaps with many other conditions such as epilepsy, learning

1. Dept. of Biochemistry, Holy Family Red Crescent Medical College, Dhaka, Bangladesh;

2. Department of Genetics and Genome Biology, NeuroGen Technologies Ltd., Dhaka, Bangladesh;

3. Department of Medicine, Dhaka Medical College and hospital, Dhaka, Bangladesh;

4. Department of Biochemistry, Dhaka Medical College, Dhaka, Bangladesh;

5. International Centre for Diarrhoeal Disease Research, Bangladesh;

6. Institute of Developing Science \& Initiatives, Bangladesh;

7. Deprtment of Anatomy, Bangabandhu Sheikh Mujib Medical University, Dhaka, Bangladesh;

8. Ministry of Health and Family Affairs, Bangladesh;

9. Institute of Child and Maternal Health, Dhaka, Bangladesh;

10. Dept. of Botany, Chittagong University, Chittagong, Bangladesh

Address of Correspondence: Dr.K. M. Furkan Uddin, Dept. of Biochemistry, Holy Family Red Crescent Medical College, Dhaka, Bangladesh 
disability, attention deficit hyperactive disorder, microcephaly and single gene disorder. ${ }^{2}$ Prevalence of Autism in USA is 1 in 68 children ( 1 in 42 boys and 1 in 89 girls) as having $\mathrm{ASD}^{3}$ but in Bangladeshi population it is $1.55 / 1000^{4}$. One of the most striking features of ASD is a 4:1 male to female gender ratio that approaches 11:1 when considering higherfunctioning manifestations of the disorder. ${ }^{5}$

The genetics of ASD is complex and highly heterogeneous and, identified genetic causes of autism can be classified as the cytogenetically visible chromosomal abnormalities (<" $5 \%$ ), copy number variants $(\mathrm{CNVs})$ (microdeletions and microduplications; $10-20 \%$ ), and single-gene disorders (<“5\%). ${ }^{6} \mathrm{CNV}$ is defined as a variable copy number of DNA segments ranging from $50 \mathrm{bp}$ to several mega bases (Mb) compared with a reference genome ${ }^{7}$. They can change gene dosage, interrupting coding sequences, and influencing neighboring gene regulation so they have a great impact on gene expression and phenotypes. ${ }^{8}$ Several human studies have established association between structural chromosomal abnormalities and ASD phenotypes suggesting that rare CNVs contribute to ASD risk. Single gene disorders are highly co-morbid to ASD and often impacted by rare/ de novo mutations in genes related to neurodevelopmental function. To date no single gene has been shown to account for a majority of ASD susceptibility. In fact, 1000 of candidate genes or loci have been implicated. ${ }^{9}$ The recent advent of sequencing technologies allowed scientist to identify more pathogenic CNVs associated with ASD. Approximately $5 \%$ of all ASD cases carry a pathogenic de novo loss of function (LOF) mutation. ${ }^{10}$ In another study, 1461 ASDs were investigated with oligonucleotide-based microarray analysis, and the CNVs surveyed were mostly inherited (69\%) among autistic individuals. ${ }^{11}$ Hallmayer's study reported that the concordance rate for autism in monozygotic twins is $60-90 \%$ and $5-30 \%$ in dizygotic twins. These twin and family studies provide some of the most convincing evidence that genetics play a considerable role in the development of the conditions. ${ }^{12}$ The meta analytic heritability estimates ranged between $64 \%$ and $91 \% .{ }^{13}$

SEZ6L2 (Seizure Related 6 Homolog-Like 2) is a compelling candidate gene at $16 \mathrm{p} 11.2$ locus for ASD whose gene mutation causes epilepsy and language disorders. ${ }^{14}$ Kumar et al. suggested an association between the SEZ6L2 gene and ASD (12/1106 ASD cases versus $3 / 1161$ controls; $\mathrm{P}=0.018$ ) in European ancestry. ${ }^{15}$ De novo, or inherited, CNV (recurrent microdeletion and a reciprocal microduplication) at the $16 \mathrm{p} 11.2$ chromosomal region are among the most frequently observed: $1 \%$ of ASD patients. ${ }^{16}$ Whole- genome screening of CNVs in population around the world have shown that their frequencies vary according to the ethnic background, allowing the distinction of population of European, African and Asian ancestries. ${ }^{17}$ It is not known whether this is also prevalent among the ASD affected individuals in population of other ancestries such as Bangladeshi population. The rationale of this research work was to examine the presence of clinically relevant CNV by targeting SEZ6L2 gene at chromosome 16p11.2 in Bangladeshi cohort with clinically diagnosed ASD.

\section{Materials and Method:}

Twenty five diagnosed ASD cases, age between 3-19 yr, were selected from Bangabandhu Sheikh Mujib Medical University; Institute of Child \& Maternal Health, and Dhaka Medical College with ethical permission from the respective institution. Samples were enrolled on the basis of DSM-IV criteria supported by Autism Diagnostic Observation Schedule (ADOS) after taking informed consent.

DNA extraction and genotyping were performed in the department of Anatomy, Bangabandhu Sheikh Mujib Medical University. Genomic DNA was purified from $200 \mathrm{ml}$ whole blood using the ReliaPrep ${ }^{\mathrm{TM}}$ Blood gDNA Miniprep System according to manufacturer's instructions (Promega Corporation, Madison, USA) and finally dissolved in $50 \mathrm{il} \mathrm{TE}$ buffer $(10 \mathrm{mM}$ Tris $/ 0.1 \mathrm{mM}$ EDTA, pH 8.0). DNA concentration was determined by NanoDrop spectrophotometer. The concentration for all qualified samples was normalized to $50 \mathrm{ng} / \mu \mathrm{l}$ and frozen at " $26^{\circ} \mathrm{C}$ for storage. Primers (forward primer for SEZ6L2 gene: 52 -CCTCTCTCTTCCCCACAAAGG32 and reverse primer: 52 TGGACAGCC TGGTTCTCTCT-32 ) were designed to amplify a region 67 bp using Primer 3 software v. 0.4 .0 (http:// bioinfo.ut.ee/primer3-0.4.0/). BLAST tool (blast.ncbi. nim.nih.gov/) was used for the designed primer to ensure that the primers chosen are specific for SEZ6L2. Primers of endogenous control FOXP2 gene were selected from the previous study. ${ }^{18}$

To detect the Copy Number Variation (CNV) genotyping of ASD samples, standard curve was generated by a duplicate series of two fold dilutions (1.56 ng, 3.125 $\mathrm{ng}, 6.25 \mathrm{ng}, 12.5 \mathrm{ng}, 25 \mathrm{ng}$ ) of a control sample of known concentration for both target and reference genes using customized cycling protocol. In addition, we used three samples as control calibrators from '1000 Genomes Project' that were ethnically Bengali. After dilution of primers of SEZ6L2 and FOXP2 genes to a final concentration of $10 \mu \mathrm{M}$, the total reaction volume for each sample was prepared to $10 \mu \mathrm{l}$ which contains $25 \mathrm{ng}$ of genomic DNA, $0.5 \mu \mathrm{M}$ of each primer, $5 \mu \mathrm{l}$ of Thermo Scientific DyNamo Flash SYBR Green 2X 
master mix. Triplicates of standard curve for internal control gene and gene of interest, control DNA sample for the amplification of internal control gene and gene of interest, and experimental samples for internal control gene and gene of interest were amplified individually in each well on separate plate following the standard protocol. ${ }^{19}$

Pfaffl $^{20}$ mathematical model was presented to determine the relative quantification of a target gene in comparison to a reference gene using Microsoft Excel spread sheet to analyze real-time PCR data for gene dosage.

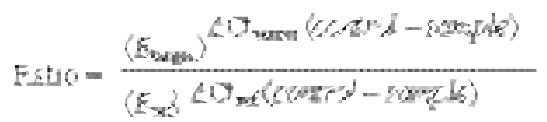

All experiments were performed in triplicate. If the ratio of signal at the locus of interest to the signal at the FOXP2 locus was below 0.7 , a loss (microdeletion) was confirmed. If over 1.2, a gain (microduplication) was called. In both cases, two copy controls were expected to have a ratio of about 1.0, indicating no copy number change in these samples.

\section{Results:}

Real-time PCR amplification efficiencies and linearity:

qPCR efficiencies were calculated from the given slopes by Microsoft Excel. The corresponding real-time PCR efficiency $(E)$ was calculated according to the equation: $E=10^{[-1 / \text { slope }]}$ through the generation of standard curve. Investigated transcripts (Fig 1 \& 2) showed high real-time PCR efficiency rates; for SEZ6L2 =2.63; FOXP2 =3.13 (Pearson correlation coefficient $\left.R^{2}>0.95\right)$.

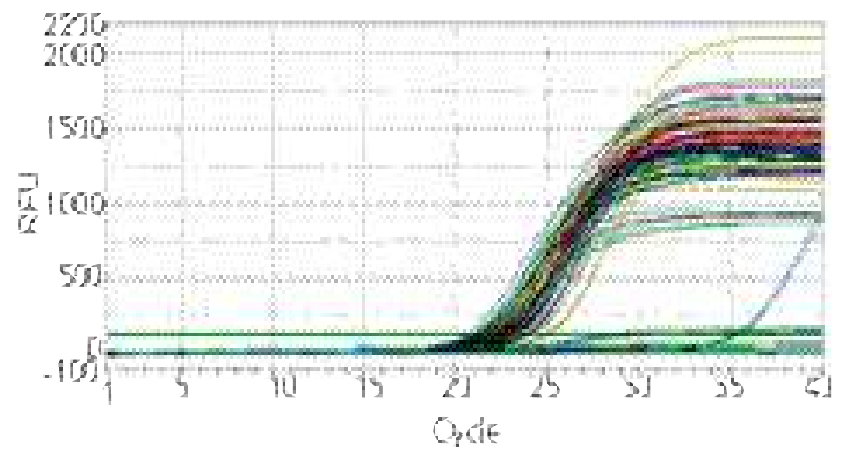

Fig. 1a: Amplification curve of SEZ6L2 gene of twenty five autistic cases in which the $C_{t}$ were between from 21 to 25.

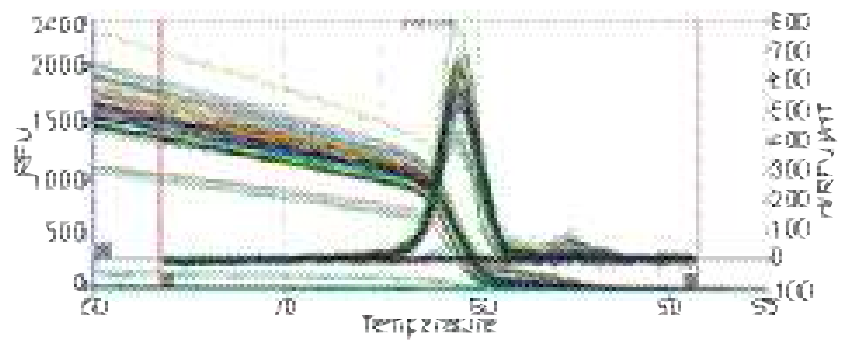

Figure 1b: Dissociation (melting) curve of SEZ6L2 gene which showed a single peak at $79^{\circ} \mathrm{C}$.

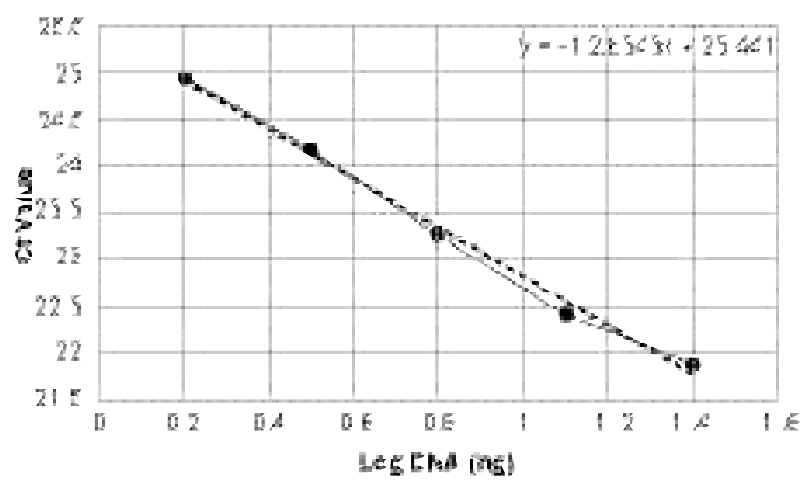

Figure 1c: Standard curve plot of SEZ6L2 gene. Slope of 2.63 indicated the amplification efficiency.

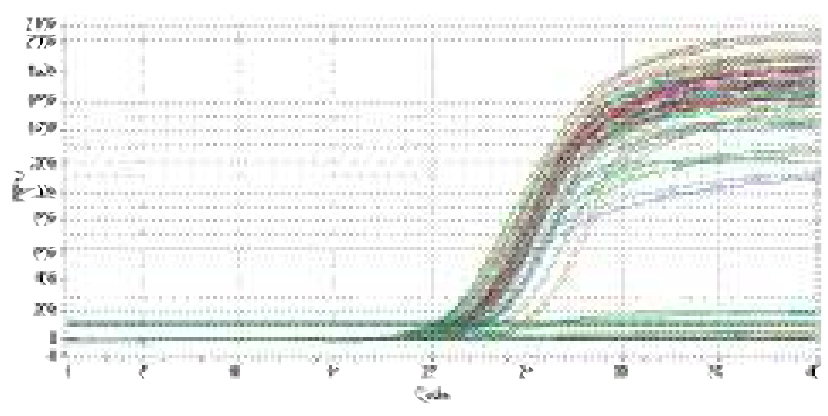

Figure 2a: Amplification curve of FOXP2 gene of twentyfive autistic cases in which the $C_{t}$ were between from 21 to 25.

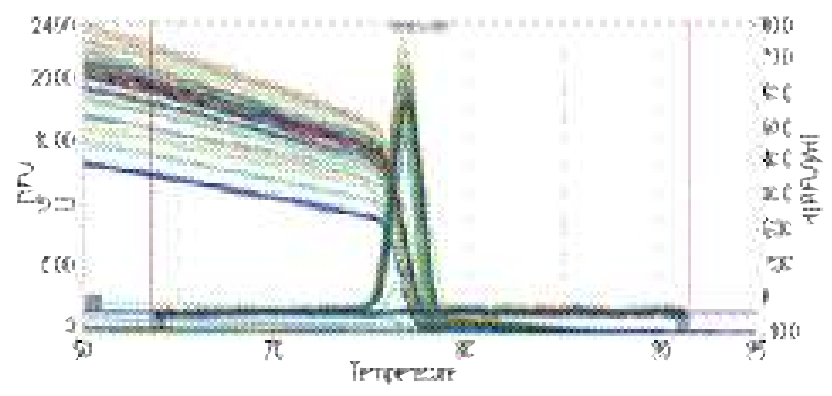

Figure 2a: 2b: Dissociation (melting) curve of reference FOXP2 gene which showed a single peak at $78^{\circ} \mathrm{C}$. 


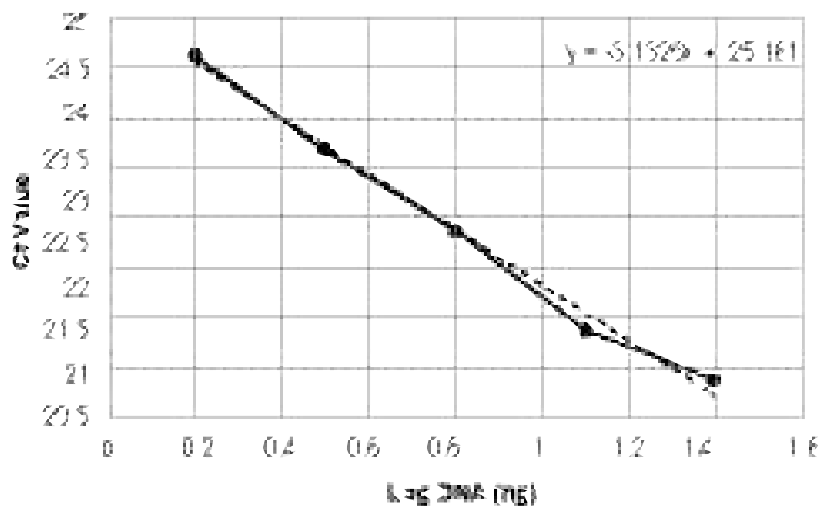

Figure 2c: Standard curve plot of reference FOXP2 gene. Slope of 2.63 indicated the amplification efficiency.

\section{ASD Cohort:}

Among the twenty five cases, two male were CNV positive and nothing founded in the female autistic cases. In two patients, we detected a duplication impacting SEZ6L2 gene (Figure 3). Overall the quantitative analysis of the SEZ6L2 gene copy number in our cohort revealed a duplication rate of $8.3 \%$.

CNV positive ASD case no 1: An eleven year (11 yr) old boy from a non-consanguineous family observed to manifest epileptic seizure from seven months of age which was stopped at the age of 8 year. He had delay in walking and speech. The boy was over weighted, 62 $\mathrm{kg}\left(95^{\text {th }}\right.$ percentile, BMI=25.9). During psychological assessment at three year of age, mental age corresponded to the age of 24 months old. There was history of postnatal infection.

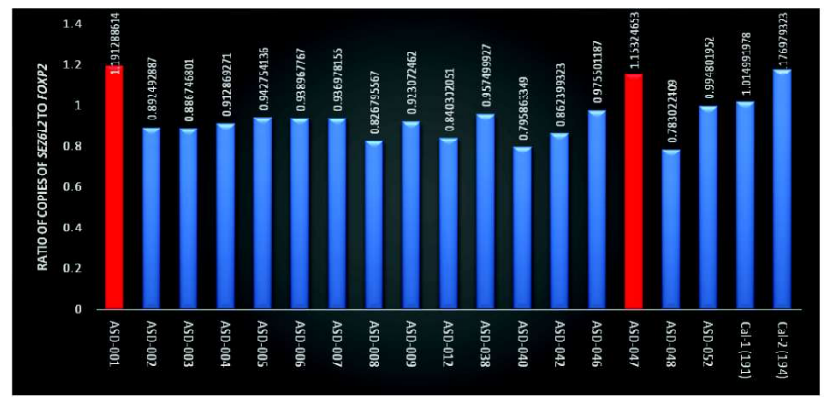

Figure 3: Comparison between target SEZ6L2 gene and reference FOXP2 gene. Copy numbers are represented by ratio of copies of SEZ6L2 to FOXP2. The Red bars show the two samples with the Copy Number Variation.

CNV positive ASD case no 2: A twelve years (12 yr) old boy from a non-consanguineous family observed to manifest epileptic seizure at the age of 9 years and speech. He was under weighted and weight, $36 \mathrm{~kg}$ (between $10^{\text {th }}$ $\& 25^{\text {th }}$ percentile). During psychological assessment at three year of age, mental age corresponded to the age of 15 month. There was h/o postnatal infection.

Table-1

Base line clinical characteristics of ASD cases:

\begin{tabular}{|c|c|c|c|c|}
\hline Characteristics & $\mathrm{N}$ & $\begin{array}{c}\text { ASD Patients } \\
\text { with CNV; n (\%) }\end{array}$ & $\begin{array}{c}\text { ASD Patients without } \\
\text { CNV; n (\%) }\end{array}$ & $\mathrm{P}$ \\
\hline Mean \pm SD age in years & - & $11.7 \pm 0.9$ & $8.8 \pm 4.5$ & $>0.05$ \\
\hline \multicolumn{5}{|l|}{ Gender } \\
\hline Male & 20 & $2(10)$ & $18(90)$ & $>0.05$ \\
\hline Female & 5 & $0(0)$ & $5(100)$ & \\
\hline Autistic sibling & 3 & $0(0)$ & $3(100)$ & \\
\hline Consanguinity present & 2 & $0(0)$ & $2(100)$ & $>0.05$ \\
\hline $\mathrm{H} / \mathrm{O}$ perinatal asphyxia & 4 & $\mathrm{O}(0)$ & $4(100)$ & $>0.05$ \\
\hline $\mathrm{H} / \mathrm{O}$ postnatal infection & 6 & $2(33)$ & $4(67)$ & 0.05 \\
\hline Development milestones delayed & 16 & $2(12.5)$ & $14(87.5)$ & $>0.05$ \\
\hline Speech \& language delay & 12 & $2(16.7)$ & $10(83.3)$ & $>0.05$ \\
\hline Language regression & 6 & $1(16.7)$ & $5(83.3)$ & $>0.05$ \\
\hline Epileptic seizure & 2 & $2(100)$ & $0(0)$ & 0.003 \\
\hline Macrocephaly & 4 & $0(0)$ & $4(100)$ & $>0.05$ \\
\hline
\end{tabular}

Note: For continuous variables Student's t test was done. For categorical variables Fisher's exact test was performed. P value $<0.05$ was considered level of significance. 


\section{Discussion:}

The cohort was composed of 20 males (80\%) and 5 females $(20 \%)$, for an overall male to female ratio (M: F) of $4: 1$ that is expected with the usual $4: 1$ ratios $^{21}$. Among the male, two (100\%) were CNV positive and nothing was found in the female autistic cases. De novo or inherited $\mathrm{CNV}$ at the $16 \mathrm{p} 11.2$ chromosomal region are among the most frequently observed: $1 \%$ of ASD patients ${ }^{16}$. A meta-analysis determined that the prevalence of it among ASD probands is $0.76 \%{ }^{22}$. But in our study the prevalence of CNV at $16 \mathrm{p} 11.2$ was $8.3 \%$ though the sample size was very small. Indeed, the prevalence of seizures in patients with ASD is between $5-38 \%$, with the frequent observation of epileptiform activity, even without clinical epilepsy ${ }^{23}$. Epileptic seizure developed in 2 cases that were interestingly $\mathrm{CNV}$ positive ( $\mathrm{p}$ value $=0.003$ ) but Zappella stated in his article that one ASD child out of four develops seizures ${ }^{24}$. In another study, it is <" $20 \% 25$. Postnatal infection was also observed in two ASD cases with CNV positive ( $P$ value $=0.05$ ) in our study. Shiow's study $^{26}$ supports this finding. Preliminary data suggests that people with the 16p11.2 microduplication have a tendency to be underweight. By contrast, a tendency to overweight and obesity has been identified with a $16 \mathrm{p} 11.2$ microdeletion, making the microdeletion the second most common genetic cause of obesity ${ }^{27}$. Jacquemont et al. ${ }^{28}$ stated that obesity had been shown to be associated with cases carries $16 \mathrm{p} 11.2$ duplication. In our study, overweight is related to microduplication though the finding was not statistically significant. Macrocephaly is frequently observed in 16p11.2 microdeletion syndrome ${ }^{29}$. The study of growth parameters revealed that macrocephaly was observed in four male individuals, while microcephaly was quite absent. This is inconsistent with our study because macrocephaly is observed only CNV negative ASD cases though the finding was not also statistically significant.

SEZ6L2 is a compelling candidate gene for ASD whose gene mutation causes epilepsy and language disorder ${ }^{14}$. Walsh and Bracken's studies had identified CNV at 16p11.2 locus in individual with developmental delay and mental retardation ${ }^{22}$. Sixteen cases $(64 \%)$ showed partial developmental delay, and twelve (48\%) cases had speech \& language delay in our study cohort, six $(24 \%)$ of them showed language regression in some extent of their age. Among the regressive cases, 1 patient $(50 \%)$ was $\mathrm{CNV}$ positive and 5 patients $(22 \%)$ were CNV negative which also indicate statistically insignificant.

In summary, prevalence of CNV of SEZ6L2 gene at 16 p11.2 might be more frequent among the
Bangladeshi ASD cohort. This pilot study describes the combined prevalence of CNV was $8.3 \%$. With only two cases harboring pathogenic copy number variants, it is difficult to conclude anything about phenotype genotype correlations with any mathematical certainty. This rate is skewed due to small sample size and do not reflect the true frequency. Epilepsy, speech disorder and postnatal infection might be more common among autistic patients with CNV at this SEZ6L2 gene.

\section{Conclusion:}

This study serves as a pilot to provide initial insight into the detection of CNV by targeting only a single gene of ASD in the Bangladeshi population. At this time, CNV testing in the Bangladeshi population would be most appropriate in a confirmatory diagnostic setting, at least until larger cohorts of matched control data become available for comparisons. Finally, this study will serve as a starting point for further genetic studies of ASD in the Bangladeshi population as well as other less studied populations to identify new candidate genes, provide more support for existing risk loci.

\section{References:}

1. Diagnostic and statistical manual of mental disorders, 5 th edn. American Psychiatric Association, Washingtn, 2013.

2. Lai MC, Lombardo MV and Baron-Cohen, S. Autism Lancet 2014; 383(9920): 896-910. https://doi.org/ 10.1016/S0140-6736(13)61539-1

3. CDC. Prevalence of Autism Spectrum Disorder Among Children Aged 8 Years-Autism and Developmental Disabilities Monitoring Network, 11 sites, United States, 2010 MMWR. 2014; 63: 1-21.

4. MOHFW. Survey of autism and Neurodevelopmental Disorders in Bangladesh: Report 2013; pp.1-166.

5. Gillberg C, Cederlund M, Lamberg K. and Zeijlon L. Brief report: the autism epidemic. The registered prevalence of autism in a Swedish urban area. J. Autism Dev. Disord. 2006; 36(3): 429-435. https://doi.org/ 10.1007/s10803-006-0081-6 .PMid:16568356

6. Hallmayer J, Cleveland S, Torres A, Phillips J, Cohen $\mathrm{B}$, Torigoe $\mathrm{T}$ et al. Genetic heritability and shared environmental factors among twin pairs with autism. Arch. Gen. Psychiatry 2011; 68: 1095-1102. https:// doi.org/10.1001/archgenpsychiatry. 2011.76 PMid:21727249 PMCid:PMC4440679

7. Clovert E, Tick B, McEwen F, Stewart C, Curran SR, Woodhouse E et al. Heritability of Autism Spectrum Disorder in a UK Population-Based Twin Sample. JAMA Psychiatry 2015; 72(5): 415-423.https://doi.org/ 10.1001/jamapsychiatry.2014.3028 .PMid:25738232 PMCid:PMC4724890 
8. Devlin B, and Scherer SW. Genetic architecture in autism spectrum disorder. Curr. Opin. Genet. Dev. 2012; 22: 229-237.https://doi.org/10.1016/ j.gde.2012.03.002 .PMid:22463983

9. ills RE, Walter K, Stewart C, Handsaker RE, Chen K, Alkan C, Abyzov A et al. Mapping copy number variation by population-scale genome sequencing. Nature 2011; 470 (7332): 59-65. https://doi.org/10.1038/ nature09708 .PMid:21293372 PMCid:PMC3077050

10. Roll P, Rudolf G, Pereira S, Royer B, Scheffer IE et al. SRPX2 mutations in disorders of language cortex and cognition. Hum. Mol. Genet. 2006; 15: 11951207.https://doi.org/10.1093/hmg/dd1035 PMid: 16497722

11. Gillberg C, Billstedt E, Sundh V, Gillberg IC. Mortality in Autism: A Prospective Longitudinal CommunityBased Study. J. Autism Dev. Disord.2010; 40 (3): 352357.https://doi.org/10.1007/s 10803-009-0883-4 .PMid:19838782

12. Weiss LA, Shen Y, Korn JM, Arking DE, Miller DT et al. Association between micro deletion and micro duplication at 16p11.2 and autism. The New England Journal of Medicine 2008; 358(7): 667-675. https:// doi.org/10.1056/NEJMoa075974 .PMid:18184952

13. Jakobsson M, Scholz SW, Scheet P, Gibbs JR, VanLiere JM. et al. Genotype, haplotype and copy-number variation in worldwide human populations. Nature 2008; 451: 998-1003. https://doi.org/10.1038/ nature06742 .PMid:18288195

14. Gazzellone MJ, Zhou X, Lionel AC, Uddin M, Thiruvahindrapuram B, Liang $S$ et al. Copy number variation in Han Chinese individuals with autism spectrum disorder. Journal of Neurodevelopmental Disorders 2014; 6: 34-40.https://doi.org/10.1186/ 1866-1955-6-34 .PMid:25170348 PMCid:PMC4147384

15. Ma L and Chung WK. Quantitative Analysis of Copy Number Variants Based on Real-Time Light Cycler PCR. Curr Protoc Hum Genet. 2015; 80: 7.21.1-7.21.8.

16. Pfaffl MW. A new mathematical model for relative quantification $\mathrm{n}$ in real-time RT-PCR. Nucleic Acids Research 2001; 29(9): 2002-2007..https://doi.org/ 10.1093/nar/29.9.e45

17. Giarelli E, Wiggins LD, Rice CE, Levy SE, Kirby RS et al. Sex differences in the evaluation and diagnosis of autism spectrum disorders among children. Disabil. Health J. 2010; 3:107-116. https://doi.org/10.1016/ j.dhjo.2009.07.001 .PMid:21122776 PMCid: PMC4767258

18. Walsh KM and Bracken MB. Copy number variation in the dosage-sensitive 16p11.2 interval accounts for only a small proportion of autism incidence: A systematic review and meta-analysis. Genet. in Med. 2011;13(5): 377-384.https: / / doi.org/10.1097/GIM.0b013e 3182076c0c .PMid:21289514

19. Zappella M. Autistic regression with and without EEG abnormalities followed by favourable outcome. Brain Dev.2010; 32(9): 739-745.https://doi.org/10.1016/ j.braindev.2010.05.004 PMid:20708360

20. Levisohn PM. The autism-epilepsy connection. Epilepsia 2007; 48(9): 933-35. https://doi.org/ 10.1111/j.1528-1167.2007.01399.x

21. Shiow LR, Paris K, Akana MC, Cyster JG, Sorensen RU, Puck JM. Severe combined immunodeficiency (SCID) and attention deficit hyperactivity disorder (ADHD) associated with a Coronin-1A mutation and a chromosome 16p11.2 deletion. Clin. Immunol. 2009; 131: 24-30. https://doi.org/10.1016/j.clim. 2008.11.002 .PMid:19097825 PMCid:PMC2692687

22. Bochukova EG, Huang N, Keogh J, Henning E, Purmann C, Blaszczyk K et al. Large, rare chromosomal deletions associated with severe early-onset obesity. Nature 2010; 463(7281): 666-670. https://doi.org/ 10.1038/nature08689.PMid:19966786 PMCid: PMC3108883

23. J acquemont S, Reymond A, Zufferey F, Harewood L, Walters RG, Kutalik $Z$ et al. Mirror extreme BMI phenotypes associated with gene dosage at the $16 \mathrm{p} 11.2$ locus. Nature 2011; 478(7367): 97-102. https:// doi.org/10.1038/nature 10406. .PMid:2 1881559 PMCid:PMC3637175

24. Shinawi M, Liu P, Kang SH et al. Recurrent reciprocal 16 p 11.2 rearrangements associated with global developmental delay, behavioral problems, dysmorphism, epilepsy, and abnormal head size. J. Med. Genet. 2009; 47: 332-341.https://doi.org/ 10.1136/jmg.2009.073015 .PMid:19914906 PMCid: PMC3158566 